\title{
Vistnok uvurderlig! - folkebibliotekerne i det litterære liv i Danmark
}

\begin{abstract}
The Danish public library as a new institution and the corresponding new librarian profession were established by law about 1918-20 and soon played an active role within circulation and mediation of literature/fiction. From a view of the sociology of literature and via a brief assessment of the concept of the literary life, the article intends to overview the position and significance of this institution in Denmark during these hundred years, and as for some special subfields more detailed and methodologically to discuss the interplays of the literary life and field. Not focusing on the growth rate of the libraries' buying and lending of fiction copies, of educated librarians, or of the increasing importance of the compensating artist royalties to the authors as evident quantitation markers, some other thematic subfields have been selected: buying structure at the book market, librarians as literature specialists, book selection as for function, taste and qualification, the library as self-interest publicity including relations literary periodicals/magazines, and examples of mediation initiatives, and finally a short adding up of today. These subfields are inquired each chronologically, there is no total account, so. Reminding the priority of the public libraries within the Danish cultural policy, there may have been little interest and focus of them by the sociology of literature; unlike this, the discussions of the article with a long historical view substantiate that the significance of the libraries in the Danish literary life has been manifold, strong and not overvalued.
\end{abstract}

Keywords: Det litterære liv, folkebibliotek, bibliotekarprofession, bibliotekshistorie, litteratursociologi, kulturpolitik

\section{Set fra Ribe seminarium i 1935}

"En endnu næppe klart paaviselig, men vistnok mangfoldig og uvurderlig Betydning for vort litterære Liv har Folkebibliotekerne, navnlig efter Bibliotekslovens Vedtagelse 1920."

Ordene stammer fra seminarielærer Ejnar Thomsen der i 1935 som ansat ved Ribe Statsseminarium skrev dem som afslutning på en ny litteraturhistorisk lærebog Dansk Litteratur efter 1870. Med Sideblik til det $\varnothing v$ rige Norden. En Hjælpe- og Arbejdsbog til højere Undervisning samt til Kreds-og Selvstudium (Hirschsprung, 1935, s. 169). Den lange titel angik en ny type bog, på et nyt og ukendt forlag, til brug bredt på gymnasier og seminarier og i folkeoplysningens fremvoksende litteraturvirksomhed; med sin pågående form og ajourføring til helt samtidig litteratur blev den en vigtig fornyer i dansk litteraturhistorie-skrivning, der ellers var noget i stagnation. Nyt var det også at trække litteraturens cirkulation ind i synsfeltet - med reverens til den litteratursociologi som 
var ved at udvikles. Der var egne biblioteker til dem som befandt sig på lærerseminariet og på katedralskolen i den adstadige stifts- og amtsby; siden 1906 havde Ribe også et lille kommunalt bibliotek, som nogle år efter loven tilmed havde fået gratis udlån. Skulle bl.a. det få betydning for det litterære liv?

Det kan undre at en akademisk iagttager ikke har et sikrere indtryk så mange år efter loven, men på den anden side kan hans tøven også markere at den nye institution ikke var så knæsat og kendt som pionererne og den tidlige bibliotekshistorik ellers typisk har fremført. Andre har peget på at først ind i 1930erne og efter en lovforbedring trådte konturerne af de nye biblioteker frem (Hjermind \& Ørom, 1981).

Thomsen selv, der også havde lyrikudgivelser bag sig, viste sig at gå mange veje i det litterære liv. Få måneder senere var seminarielæreren fra provinsen blevet ny professor i dansk og nordisk litteratur ved Københavns Universitet - landets mest fremtrædende litteraturfaglige stilling. Den tidligere kostskolelærer på Bogø og nu 38årige magister blev ansat efter såvel videnskabelige som undervisnings- og formidlingsmæssige kriterier - hans nye bog sigtede på både skolers pensum og de voksens egenlyst, den nyere litteratur var for alle - og han blev en skattet underviser for stud.mag.er gennem et par årtier. Nogle så ham som en typisk højskolefigur, og som tillige engageret i både folkeuniversitet, forfatterforening og litteraturselskaber, foruden redaktør, flittig anmelder og bred foredragsholder var han bredt optaget af litteraturens cirkulation og befolkningens læsning. Som en vigtig dansk litteraturskikkelse modificerede han således en tidligere litterær eksklusivitet - fremdeles også da han 1012 år var timelønnet underviser på Statens Biblioteksskole, så kommende gymnasie-dansklærere og folkebibliotekarer havde ham til fælles. Til historiens cirkel hører i øvrigt at Ribes folkebibliotek i dag har til huse i den seminariebygning hvor Thomsen virkede dengang!

\section{Det litterære livs samspil og udvekslinger}

På hvilken måde giver det mening at tale om en ny betydning for det litterære liv, og på hvilket tidspunkt bliver folkebiblioteket væsentligt her? Det litterære liv er et accepteret begreb bredt om omgang med og udvekslinger af udgiven litteratur i offentligheden. I litteratursociologien tales mere skematisk om det litterære system eller det litterære felt med aktører og institutioner, funktioner og processer i forskellige led med faglige, smagsmæssige og økonomiske interesser i produktion, distribution og reception af litteratur. (Escarpit, 1972; Furuland, 1989; Hertel, 1999). Med inspiration i litteratursociologien er intentionen med denne artikel via en række nedslag i temaer og subfelter at vise at bibliotekerne har haft en større plads og betydning end fremstillinger af litteratursystemet eller det litterære liv eller felt oftest har vist.

Omkring 1915-20 konstitueredes det skøn- og almenlitterære liv af forlagene med nyudgivelser og klassikere, københavnske dagblades eksklusive kritik, universitetsuddannelser og forskning i litteratur, forskellige typer tidsskrifter, gymnasie- og mellemskole-pensummet med dannelsestænkning, forfatterforening og enkelte lejebiblioteker og fx Kvindeligt Læseselskab, men også så småt af nye tiltag som studiekredsbevægelse, voksenoplysning og små offentligt tilgængelige folkelige bogsamlinger. (Et særegent samspil mellem det eksklusive og det brede var det at overbestyreren for Københavns kommunale biblioteksvæsen mellem 1898 og 1912 var en af tidens renommerede litterater, dr.phil. Valdemar Vedel der samtidig siden 1895 var docent og 1911-30 professor i almindelig litteraturhistorie ved Københavns Universitet).

Trods biblioteksfunktioner og bogsamlinger ikke var ukendte forud, var de nye danske lovfæstede biblioteker, ret parallelt med andre lande i begyndelsen af 1900-tallet, en væsentlig nydannelse; imidlertid synes de ikke at have haft den store plads i den internationale litteratursociologi (fx Escarpit, 1972 - sc. 1958/1968), hvilket bl.a. hænger sammen med at denne institutionscirkulation i store bogmarkedslande har fyldt (relativ) mindre. Men heller ikke i litteratursociologi-traditionen i de skandinaviske lande, med deres stærke kulturpolitiske prioritering af bibliotekerne, har disse fyldt, hverken i systematiske oversigtsbøger som Bøger og brugere, Bok-Norge, Litteraturen i mediesamhället og senest Litteraturens rundt eller i forskningslitteraturen - med Avdelingen för litteratursociologi ved Uppsala Universitet som tydeligste undtagelse. (Andreassen, 2006; Bay \& Jørgensen, 1979; Handesten, 2018; Steiner, 2009; Svedjedal, 2012; Winge, 1979).

Forbindelsen mellem bibliotek og litteratur, Norden rundt, synes snarest at skulle findes for det første i redegørelser fra statslige myndigheder, hvor begrebet litteraturformidling også dukker op som et vigtigt begreb 
i det litterære system, i Danmark fx tilbage i større ungdomsundersøgelser omkring 1950, eller i betænkningen Bøger i Danmark (1981), dvs. knyttet til statslig kulturpolitik. For det andet findes forbindelsen opdyrket i biblioteksmiljøer og især omkring biblioteksuddannelser, hvor litteratursociologien (og bibliotekshistorien) således også fik en oplagt placering; nogle af de første danske læserundersøgelser fandt sted i tilknytning hertil (jfr. fx Iversen; Hvem læser hvad i Silkeborg?, 1944, s. 260 og s. 152-154.), og Læste bøger blev et pionerstudie (Elberling \& Bruhns, 1965/67). Fra 1970erne var litteratursociologien biblioteksstudiets relevante synsvinkel på skønlitteraturen, med fx oversigtsbogen Litteratursociologi. En antologi (Munch-Petersen, 1989/1995) og siden 1990erne en del specifikke undersøgelser i feltet mellem bibliotek og litteratur ved Danmark Biblioteksskoles/Det Informationsvidenskabelige Akademis litteraturuddannede forskere, ret parallelt med tilsvarende institutioner i Norge og Sverige (jfr. Karner Smidt, 2013). Det er linjerne herfra der søges fulgt tilbage gennem de moderne danske folkebibliotekers hundrede år - hvor det litterære liv ikke har været statisk, men bestandigt forandret med skiftende positioner mellem aktørerne og med betingelserne for kommunikation og opinionsdannelse.

\section{Folkebibliotekernes plads i Danmark}

Det litterære livs fundering i marked og civilsamfund havde til ind i 1900-tallet ikke mødt megen offentlig indsats eller påvirkning, ud over fx pligtaflevering, nogle særlige handelsregler, undervisningsbestemmelser og lidt statslig st $\varnothing$ tte til enkelte forfattere. Formelt og strukturelt var det et vigtigt skridt da kommuner fra 1920 fik mulighed for, og senere forpligtelse til, at oprette egentlige folkebiblioteker til erstatning af de foreningsdrevne (og ofte offentlig støttede) folkebogsamlinger der havde været i gang gennem nogle årtier. Det nye var en ny aktør placeret i distributions- eller cirkulationsleddet - med en lovfæstet baggrund, en offentlig finasiering uden kommercielle interesser og en uddannelsesbaseret faglig styring.

På den ene side måtte biblioteker oplagt have en del med en litteraturbåren eller litterær kultur at gøre; de trykte medier var tidens helt primære; på den anden side var hovedsigtet med de nye biblioteker ikke primært rettet mod det (skøn)litterære liv. De var tænkt ind i kundskabsliv og folkeoplysning. Det var en oplysningsinstitution der ikke blot var et praktisk distributionsled, men snarere havde en opgave med at skabe en sund befolkning gennem læsning - som en del af både demokratisk udvikling og samfundsmæssig vækst (Skouvig, 2004, s. 47f).

Folkebibliotekerne bød - eller brød - ind i det litterære system. Strukturelt set centrerede det sig om to forhold: for det første kom en ny aftager på bogmarkedet, et offentligt indkøb der påvirkede handel og omsætning; for det andet igangsattes en ny cirkulation af bøger via udlån til befolkningen, en gratis udveksling til fremme og $\emptyset$ gning af læsning, en påvirkning via såkaldt formidling. Hertil knytter sig to nye forhold: dels opstod der i forhold til indkøbet en problemstilling om dækning til forfatterne for tabt indtægt pga. mindre almindeligt markedssalg, den såkaldte biblioteksafgift som med årene blev en betydningsfuld sag; dels fremkom der med institutionen en ny professionel, statslig uddannet aktør ved siden af akademiske litterater og skolesystemets undervisere bibliotekarerne blev på sigt en vigtig gruppe.

Det mest indlysende kunne således være at se på betydningen for det litterære liv via anskaffelser af bøger, udlån af bøger, biblioteksafgift og bibliotekarprofession, hvor man overalt og over år vil se kvantitativ ekspansion og stigende effekter. Men herudover er der mange andre - måske mere oversete og nok så interessante forbindelser til det litterære liv og litteratursystemets praksis som i nogle nedslag, især i den tidlige tid, og nogle udviklinger skal belyses i det følgende.

Skønlitteraturen indoptoges fra begyndelsen i bibliotekets oplysningsparadigme i en spænding med både dannelse, service og oplevelse, og i en lang turbulens forvikledes den med smag, opinion, kunst, censur, underholdning etc.; det synes i dag en pointe at skønlitteraturens plads ikke blot synes påfaldende intakt ift. en 100-årig tradition, men også på nye præmisser er blevet et af bibliotekernes mest mangfoldige og synligste satsningsområder - skønlitterær formidling som mantra. Det er hensigtsmæssigt at medtænke den formidlingshistoriske struktur som Rasmus Grøn (2010) har lagt frem: en konfirmativ fase med et oplysningsparadigme 1920-65, en formativ fase med et serviceparadigme 1965-2000 og en performativ fase med 
et oplevelsesparadigme fra 2000 (jfr. Lund 2000; Lund, 2001), men den kan ikke dække alle bibliotekslivets aktiviteter.

Dertil er det oplagt at betragte folkebiblioteket både kulturpolitisk og litteraturpolitisk; fra midten af 1900-tallet blev det en hovedhjørnesten i dansk kulturpolitik. Antagelig har der historisk fandtes væsentlige dispositioner: dels at folkebibliotekernes arbejde med skønlitteraturen efterhånden blev et element i kulturpolitikkens (og folkeoplysningspolitikkens) fokus på skønlitteraturen (også før der var noget som mere officielt hed kulturpolitik), og dels at den store vægt der blev lagt på bibliotekspolitik har holdt en mere omfattende litteraturpolitik tilbage.

Med ønske om også metodisk og kildemæssigt nærmere at unders $\emptyset$ ge det litterære livs forbindelser gennemgås i det følgende en række udvalgte temaer/delfelter - frem gennem de hundrede år siden 1920: den nye aktør på bogmarkedet, bibliotekarer set i relation til andre litteraturfagfolk, det højt prioriterede bogvalg, spørgsmålet om en biblioteksmæssig særoffentlighed, mønstre omkring litteraturtidsskrifter, nye særlige formidlingstiltag midt i 1900-tallet og endelig en kort status opstilling for nutiden.

\section{'Indbruddet' i bogmarkedet}

Der var højkonjunktur omkring 1900-århundredeskiftet hvor offensive forlag på bogmarkedet med flere moderniseringstræk og nye typer udgivelser orienterede sig efter foreningsdannelser, ny almenskolelov, stigende voksenoplysning og et $\emptyset$ get læsepublikum. Spørgsmålet her lyder hvordan markedet forholdt sig til afsætningsmulighederne til de fremvoksende offentlige bogsamlinger og biblioteker?

Da folkebogsamlingerne sluttede sig sammen til Foreningen Danmarks Folkebogsamlinger, gik den - støttet af Kultusministeriet - i forhandling i 1905-06 med Den danske Boghandlerforening, der dengang primært var en forlæggerorganisation. Hovedanliggendet var rabatordninger ved $k \emptyset b$ af bøger til bogsamlingerne, og en overenskomst endte med at boghandlen ydede $25 \%$ rabat på bogpriser mod at kunne se frem til at sikre de organiserede forlag et støt voksende afsætningsmarked, og idet bogsamlingernes modydelse var via Bogsamlingsbladet (1906-1920) at sprede vigtig information/anbefaling om bøger ud til lederne af bibliotekerne til fordel for hele læsekulturen og oplysningen. Det er det første formaliserede signal om bogbranchens interesser i de offentlige folkelige biblioteker med gratis udlån. Skønt dette salg var i sin vorden og kun vejede lidt i brancheomsætningen, var det tydeligvis et nyt læsemarked man gik i møde. Eksempelvis bidrog tidens mange bogserier/biblioteker, samlede værker samt folke- og mindeudgaver af de kendte danske forfattere til både praktisk struktur og litterært præg i anskaffelserne i de omkring 1000 bogsamlinger landet over; der var 'gelænder' og 'alibi' hos især det altdominerende Gyldendals mange samleudgaver, hvilket biblioteksmønsterkatalogerne fra 1902 og 1923 tydeligt godtgjorde. Om fx folkeudgaven af Sophus Bauditz' værker hed det i Bogsamlingsbladet i 1911: “...vi maa være overordentlig glade ved, at vi nu kan købe alle hans Bøger for $15 \mathrm{Kr} . "$. Men der var også forbehold over for tidens ekspanderende bogproduktion; fem år efter præciserede overbibliotekar H.O. Lange købersidens synsvinkel således at i “... alle Kredse er Grænsen for Kjøbeevne overfor Bogmarkedet snart naaet" (Lange, 1916-17 I, s. 23).

I bogbranchen blev det først for alvor et diskussionsemne omkring 1920, især formuleret omkring afsætningen: var det gratis udlån til skade eller til gavn for forlagenes og detailleddets bogsalg? Det dominerende Gyldendal forklarede sig med at salg til private kunne agere og ekspandere parallelt med bibliotekernes bogbetjening, som man så som en folkelig bevægelse; i året hvor folkebiblioteksloven vedtoges, priste Poul Levin (forfatter, kritiker, litteraturhistoriker dr.phil., redaktør, forlagskonsulent mv.) i forlagets officielle 150 års-jubilæumsbog de folkelige biblioteker og lovede at forpligte sig kulturelt over for den læsetrang i befolkningen som bibliotekernes indkøbs- og udlånsstatistikker viste. Der var glæde over den nye aktør, samdrægtighed mellem køb og lån på læsemarkedet, uden grund til bekymring - for det store hartkorn!

Allerede før bibliotekslov og faguddannelse var samvirket med bogbranchen således i gang; det var i realiteten statens endnu knap formulerede bibliotekspolitik og de fremtidige statstilskudsmuligheder branchen havde indgået aftale med i 1906; det var strukturelt ny for det liberale bogmarkeds mønstre - med lange perspektiver 
fremad for litteratursystemet. Johan Svedjedal (1993, s. 558ff) peger på samme betydning for Sveriges bogmarked. Også på børnebogsområdet var sammenhængen mellem det moderne bibliotek og vækst i forlagenes udgivelser ubetvivlelig (Rabatspørgsmaalet, 1906, s. 7ff; Hvenegaard Lassen, 1962, s. 68ff; Frøland, 1974, s. 248f; Fortegnelse, 1902; Bogfortegnelse, 1923; Omtaler af skønlitteratur, 1911-12, s. 20; Winge, 1976, s. $66 \mathrm{ff})$.

Årtier frem var der støt stigende bestandstilvækst i folkebibliotekerne til gavn for bogmarkedets omsætning og med forskellige former for centrale og lokale købs-/leveringsaftaler og rabatsystemer. Bibliotekerne kunne og skulle fremover blive egentligt sikkerhedsnet for forlags udgivelser, i særdeleshed gjaldt det ikke mindst børnebøger/billedbøger, hvor prisniveauet typisk sattes efter institutionsaftaget; der har været bogvalgspolitikker som har prioriteret ny dansk skønlitteratur (i 1994 understreget af et kulturministerielt udvalg, En politik for litteraturen), og bibliotekerne stiftede Nyt dansk Litteraturselskab i 1940 til særlige magna-print udgivelser. Ny bibliotekslovgivning fra 1960erne fremkaldte en voldsom stigning af titler på markedet, tegneserier inklusive, og $\mathrm{fx}$ succesen for 1970ernes realistiske ungdomsroman skyldtes mest bibliotekscirkulationen og ikke privatkøbet. Der havde været et ulige mindre litterært liv uden folke/skolebibliotekerne, med børn som tilmed flittigere lånere end voksne (Weinreich, 1985).

På bibliotekerne fremkaldte det jævnlige diskussioner - beklagelser fra forlæggerside - om at indkøbet $\varnothing$ delagde markedets ' $\varnothing$ kologiske' balance; men selv under de gode konjunkturer for befolkningens adgang til billigb $\emptyset g e r$ og bogklubber i 1960-70erne var der ikke noget nævneværdigt fald i institutionsindkøbet. Den fysiske lydbog blev også længe primært et bibliotekscirkuleret medie. Først i 1980erne kom en synlig opbremsning i bogindkøb pga. kommunale bevillingsnedskæringer, hvilke påvirkede branchen på oplagsstørrelse, ikke titelmængde, hvorefter bogpriserne steg. Denne branche-biblioteksmekanisme sås især tydeligt vedrørende kriminal/spændingslitteraturen - der havde fået den øgede opmærksomhed blandt lånerne som pressede bibliotekerne til at indkøbe titlerne uanset forlagenes øgede priser og gevinster. De "bibliotekstækkelige" bogtyper steg mere i pris end andre bøger, og da de også var gennemgangsbøger, blev det en betænkelig markedsmekanisme (Worsøe-Schmidt, 1997).

De nye bogtyper, e-bøger og net-lydbøger, har de seneste år medført nye udfordringer for branchen i forhold til bibliotekerne, idet den digitale eksemplar- og købsstruktur vanskeligere kan forenes med bibliotekernes tradition for at stille gratis til rådighed. Den samdrægtighed litteratursystemet ellers i hovedsagen har haft opbygget er således blevet uvant konfliktfyldt, og sammen med ophavsretsspørgsmål er det også en kulturpolitisk udfordring; specielt hvis folkebiblioteket tillige bliver en slags egentlig producent på bogmarkedet, kan det få en ganske ny konsekvens i det litterære liv. (Worsøe-Schmidt, 2017).

Bibliotekernes indbrud på bogmarkedet gav også forfatterne anledning til overvejelser - med lange perspektiver. I 1918 fremkom et forslag om et lille vederlag for hver bog indkøbt og udlånt i bibliotekerne -"Fem- $\varnothing$ ren", og efter godt 25 år med jævnlige diskussioner endte det med en lovmæssig ordning omkring en afgift til forfatterne, den såkaldte biblioteksafgift, eller bibliotekspengene, som siden løbende er blevet voldsomt udbygget og justeret til ud over forfattere også at omfatte oversættere mfl. Ordningen er velbeskrevet i dansk kulturhistorik (Johansen, 1996), og skal ikke forfølges nærmere her, udover at den må ses som en af de meget vigtige og mærkbare konsekvenser af at folkebibliotekerne fik stærke plads i den litterære cirkulation - mellem markedet og staten. Afgiftens betydning for forfattere, ikke mindst børne- og ungdomsbog-forfattere, har været og er meget stor derved at den tegner sig for det største beløb som staten overhovedet afsætter til direkte at støtte litteraturen med. Kulturpolitisk eller måske snarere litteraturpolitisk rummer dette afgiftssystem - i sin nærmest uafvendelighed - både konstante balanceudfordringer og paradokser, bl.a. at det nu reelt anses for egentlig kunstst $\varnothing$ tte frem for erstatningsvederlag, samtidig med at de skønlitterære forfattere får den mindste del af millionerne, og at det med den automatiske afhængighed af bibliotekernes boganskaffelser afstedkommer udviskede kvalitetskriterier (Worsøe-Schmidt, 1994).

Bibliotekerne fik betydning for både de materielle og immaterielle markedsproducenter - indbruddet trak spor. 


\section{Bibliotekarerne og litteraturfagfolkene}

Ud fra erfaringerne med lærerne som fritidsbestyrere i civilsamfundets filantropiske bogsamlinger begyndte konturerne af betydningen af den heltidsbeskæftigede faguddannede bibliotekar at tegne sig i 1910erne: en ny type professionel der stod for dels formaliserede metoder og standarder med både dybde og overblik over bogbestand og dels dannelse, menneskekundskab og stærk etos i forhold til bogvalg og vejledning (Skouvig, 2004). Med denne kontur etableredes Statens Biblioteksskole og en ny uddannelse i 1918 og frem gennem 1920erne. Den adgangsgivende studentereksamen - "... en solid og værdifuld human Almendannelse ... gennem Studiet af nyere Kultursprog og deres Litteratur", som det hed om 1903-gymasieordningen - havde ikke mindst givet danskfagets litteratur en stærk vægt, der frem gennem et ekspanderende gymnasium holdt til omkring 1970 (Skovgaard-Petersen, 1976, s. 244ff; Andersen, 1970).

Skønt en bibliotekar skulle arbejde bredt med mange funktioner, var der ikke desto mindre kommet en helt ny professionel aktør i lokalsamfundet til arbejdet med skønlitteraturens cirkulation. Qua lovgivningen var det således en offentlig ansat embedsmand man fik uddannet, og gerne anset i niveau med provinsbyens rektor, overlærer og præst. Ca. to tredjedele af de uddannede var kvinder, og de etablerede sig ved siden af andre af det litterære livs aktører og sideløbende med et støt stigende antal cand.mag.er og magistre i sprog- og litteraturfag der bredte sig i oplysnings- og litteraturlivet.

Ind i 1930erne havde denne nye profession nået et volumen - over 300, omend endnu langt til en bred dækning af landet - så det gav mening at tale om en stand af dansk uddannede folkebibliotekarer; en stand der rekrutteret fra især mellemlag og embedsmiljø havde en idealistisk tro på oplysning, og som med den borgerlig-humanistiske dannelsestradition og bogmediet i centrum skulle få en betydelig indsigt i og kontrol med befolkningens læsning. Såvel bibliotekstilsynets som uddannelsens ledere ytrede sig de næste årtier flittigt om denne dannelse - man kunne stadig tale om folkeopdragelse; med præg af både kald og formynderi gjaldt det skønlitteraturen som almenvellets gode samvittighed. Efterhånden blev bibliotekarenes selvforståelse påvirket både af tidens politisk orienterede oplysning og kulturkamp og af en klarere lønarbejderbevidsthed; frem mod 1960erne kan man tale om neutrale teknokratiske tankegange, svarende til hvad der i litteraturformidlingshistorikken er kaldt serviceparadigmet. I 1970erne forøgedes bibliotekarstanden med ca. 150 årligt; notorisk søgte mange studerende helt frem til århundredeskiftet bibliotekaruddannelsen af interesse for litteraturlæsning (Hansen, 1937; Hjermind \& Ørom, 1981; Iversen, 1978; Skouvig, 2004; Grøn 2010).

Undervejs $\mathrm{i}$ denne historik har der været mange forbindelseslinjer til det litterære livs andre miljøer og faguddannede personer. Folkebiblioteksmiljøet var på den ene side vokset ud af et ældre statsligt biblioteksmiljø med akademisk litterærhistorie, og på den anden side af civilsamfundets nye folkelige bogsamlinger der blev drevet af skolelærere. Da Statens Bogsamlingskomite tog fat på uddannelsesspørgsmålet omkring 1910, var en række af de centrale akademiske biblioteksfolk og opinionsdannere netop litterater, hvoraf flere netop blev undervisere på den nye Statens Biblioteksskole.

Blandt de nye uddannede kunne også ses kombinationer mellem bibliotekaruddannelsen og universitetseksamener, foruden en del teologer således flere magistre med litteratur og sprog som fag, en del også med ufuldførte studier. Det er ikke store tal (de siger også noget om svære beskæftigelsesforhold for universitetskandidater), men dog kvalifikationsprofiler der kan følges i biblioteksarbejdet, og flere af de dobbeltuddannede endte som ledere. Omvendt var der også bibliotekaruddannede som flyttede til eller knyttede sig til andre dele af litterær virksomhed, således i AOF, radioens litteraturafdeling, højskolerne, studiekredsvirksomhed, forlagsverdenen, journalistikken, i kulturpolitik foruden en del med eget forfatterskab og oversættelsesarbejde; især mange børnebibliotekarer har været virksomme bredt i det børnelitterære felt. I de samme årtier midt $i$ århundredet var der tilsvarende også akademiske litteraturfagfolk som fra deres forskellige pladser i forskning eller oplysningsarbejde tænkte kongenialt med og inspirerede folkebibliotekets arbejde med skønlitteratur - foruden en del af dagbladenes magisterkritikere. 
I forhold til uddannelsens vægt på litteratur blev der hentet litteraturfagfolk udefra til undervisning på Statens Biblioteksskole (sc. sidebeskæftigelse), således bl.a. den nævnte professor Ejnar Thomsen fra universitetet, senere i de fastansattes tider på Danmarks Biblioteksskole var mange af underviserne både bibliotekarer og litteraturkandidater. I århundredets sidste årtier var en stor del af skolens underviserstab litteraturmagistre, $\mathrm{i}$ overensstemmelse med studieordningens prioritering af litteratur, litteraturhistorie, kritik etc., men med de seneste uddannelsesændringer svækkedes bibliotekarprofessionens forbindelse til litteraturfagfolk, og en lang tradition for kompetencer med vægt på autoritativ indholdsekspertise ændredes i retning af formidlingsaktiviteter med vægt på læser og litteraturbruger (Grøn \& Balling, 2012). Folkebibliotekaren er stadig en aktør i systemet, men i gradvis ændret skikkelse, og bibliotekernes arbejde med skønlitteraturen overtages i stigende grad af personer der er uddannet i litteraturvidenskabelige fag - typisk kaldet litteraturformidlere.

\section{Bibliotekets sakrosankte bogvalg}

Ikke alle markedets bøger blev lukket ind i institutionen. Henover de skiftende forhold har opbygningen af bestanden og bogvalget stået meget centralt. Skønlitteraturen gav som nævnt på mange måder de største udfordringer: den var ikke det vigtigste i det nye folkebiblioteks grundlæggende oplysningstanke, men havde til gengæld den største efterspørgsel fra befolkningen, dens vurderingskriterier var ofte vanskelige, og den afstedkom de største diskussioner i både i bibliotekarkredse og en større offentlighed. Det er rimelig velbeskrevet i folkebibliotekshistorikken, og blot nogle af tovets knuder skal fastholdes her og især ses sammen med hvordan det professionelle biblioteksmiljø tænkte om litteratur.

Loven stillede krav om at opbygge en bogbestand med bredde, kvalitet og alsidighed, og foretaget med både viden og smag, men uden fordomme og censur - idealet var at "Det bedste af den danske Litteraturs Frembringelser" kom ind i den nye biblioteker. Reelt var det et nyt blik på den litterære cirkulation der blev institueret, idet skønlitterær læsning som område dog først nævnes eksplicit i lovrevisionen i 1931. Gennem tiden blev bogvalget set som et af bibliotekets/bibliotekarens helt vigtige opgaver, af betydning for befolkningens "Dannelsesstade", og fremstillet højstemt i bibliotekslærebøger som noget næsten sakrosankt. Allerede i 1920erne, og i bogsamlingerne forud som nævnt, var der en del vaklen og mangel på faglige kriterier over for den skønlitteratur der var mere efterspørgsel på end biblioteksfaglig prioritering af. Men der var strategier med kvotering med kun én skønlitterærbog for hver to faglitterære, en karenstid på de nyeste bøger som forhalede lånesulten og gav forlagene mulighed for mere initialt markedssalg, en vis pædagogisk orienteret censur og differentieringsfors $\emptyset \mathrm{g}$ i det brogede landskab af "Morskabslæsning, Knaldromaner, Døgnlitteratur" og de bøger der med kort levetid "... skæmmes af en forloren Stil eller af en sødladen Sentimentalitet, Fornemhedsgriller, overspændt Religiøsitet eller anden Usundhed", som det hed i tidens mere moralske end faglige karakterisering (Lærebog, 1922, s. 28; Hansen, 1937; Lærebog, 1945; Winge 1976, s. 159f).

Stadig i 1940erne fremhævedes det faglige oplysningsideal "Bibliotekets rette Skikkelse som Oplysningsinstitution og ikke som Lejebibliotek", og holdningen var ikke blot at skulle efterkomme en efterspørgsel men også bidrage til at kvalificere denne. Der var beretninger om det statslige tilsyns omrejsende overvågning for at sikre mod smagsforfald lokalt. Set fra en dannelsestænkning var udfordringen at befolkningen ikke efterspurgte klassikerne, men den nye og samtidige litteratur, i en grad at det nemt kunne underminer det normdannende korpus som fælleskataloger og mønsterlister søgte at bygge op. Der var udfordringer mellem dansk og oversat skønlitteratur, hvor en kulturelt betinget prioritering af den nationale blev modgået at den større efterspørgsel på den markedsmæssigt langt mere omfangsrige udenlandske litteratur. En fordeling 60-40 både af bogbestand og af udlån mellem skøn- og faglitteratur regnedes for normal, under besættelsestidens læsekonjunktur var det snarere 65-35, og en fjerdedel af lånerne læste kun skønlitteratur. I 1950erne forsøgte man at fundere bogvalget i empiriske læserundersøgelser og disses ret nye metoder. På mange var det et uberegneligt dyr man havde lukket indenfor i det pæne hus - med den samtidige skønlitteratur som standende og største udfordring. Helt frem til 1960erne rangeredes bogvalget som det allermest centrale i bibliotekarstandens arbejde og selvforståelse, og det skønlitterære havde en hellighed der først under det efterfølgende serviceparadigme neutraliseredes noget - for i dag typisk at være administrativt centraliseret (Lærebog 1945, s. 174ff; 1953; Hjermind, 1981). 
Større kvalitets- og anskaffelsesdebatter omkring skønlitteraturen har trukket helt ud i den st $\varnothing$ rre offentlighed, fx omkring Morten Korch i 1940erne, tegneserier i 1950erne, triviallitteratur og pornografi i 1960erne samt fx omkring Bent Hallers (såkaldte) trøstesløshed i ungdomsbogen i 1970erne. Dannelsesstrategien om trappestigen - at 'læse lånerne op' til gradvis bedre litterær kvalitet - fik nogenlunde samtidig et modspil i en genretænkning, hvor (trivial)litterære genrer som kriminallitteratur, science fiction, western, pornografi og tegneserier havde og måtte bedømmes på hver deres specifikke kriterier - frem for en generel litteraturnorm; i ekspansionstider var disse genrer også lettere at lukke ind - samtidig med at opmærksomheden på det folkelige, på brugslitteratur og på det kulturelle demokrati indfandt sig.

I midten af 1980erne accentueredes debatten om bogvalget voldsomt til et længere forløb med tråde til væsentlige strukturelle træk omkring smag, kulturpolitik, anvendelse af offentlige ressourcer, bestsellerisme, nye medier og overhovedet bogens overlevelse $i$ en medietid. For første gang stagnerede eller faldt bibliotekernes indkøb og bestandstilvækst - ligesom nyrekruttering af bibliotekarer - pga. svindende kommunale bevilliger; det gav sammen med $\emptyset$ get bogproduktion $\mathrm{i}$ faldende oplag stigende priser og opmærksomhedskoncentration og dermed - samtidig med kritikernes svindene autoritet - en $\emptyset$ get efterspørgsel fra lånerne på især populærlitteratur, som yderligere satte bibliotekerne under pres.

Den litterære cirkulation kunne ikke ignorere folkebibliotekernes ageren. Det affødte en del konferencer, debatbøger og offentlige diskussioner med det interessante aspekt at det var hele det litterære liv - forfattere, kritikere, forlæggere og forskere - der udefra kritiserede bibliotekernes knæfald for efterspørgslen, medens bibliotekarerne indefra måtte forsvare sig med hensynet til lånerne. Systematiske undersøgelser for året 1989 viste at der bredt landet over var en stigende vægt på efterspørgsel af skønlitteraturen, at en del smallere litteratur blev valgt fra og at funktionen som sikkerhed under forlagenes udgivelser var væk, samt at bogvalget landede hvor litterær kvalitet kunne kombineres med popularitet. På den ene side kunne en forsker konkludere at situationen var et ryk ind $i$ en postmoderne situation, hvor en lang normativ tradition var under opløsning og decentrering hvilket mest lignede et kulturpolitisk tomrum. På den anden trøstede en anden forsker efter undersøgelser af det faktiske hjemlån med at det litterære liv i bibliotekerne var mere kvalitativt solidt end bogkøbernes, og at lånernes skønlitterære læsekultur var mere bred end hvad man kunne aflæse på boghandlernes bestsellerlister (Japsen, 1992; Secher,1995; Secher, 2000).

Lidt skarpt trukket op - i slutningen af 1900-tallet var den moderne demokratiske stats oprindeligt kvalitativt og kulturpolitisk begrundede folkeopdragende prioritering af at stille skønlitteraturen til rådighed for befolkningen 'stødt mod muren'; folkebibliotekets konstante tumlen med bogvalg og kvalitet var under serviceparadigmet blevet til forskelsløs gratis bogforsyning, til et system med bogforbrug pr. autonom efterspørgsel og automatisk selvbetjening, som var så værdineutralt at det primært kunne måles og evalueres kvantitativt. Af den aske opstod ikke et fornyet bogvalg og indkøb, snarere et skift fra vægt på litteratur til vægt på læseoplevelse; der kom vægt på ny litteraturformidling og nye mødesteder under oplevelsesparadigmet i det nye århundrede (Grøn, 2010; Grøn \& Balling, 2012).

\section{En særoffentlighed eller en åben del af det litterære liv?}

To vigtige forhold kan siges at spille ind på bibliotekets håndtering af bogvalget og på bibliotekarens litteraturvurdering qua aktør i litteratursystemet.

For det første opbygningen af et eget receptionssystem, der også har en lang bølgerig historik. Som nævnt var allerede Bogsamlingsbladets modydelse til bogbranchens prisrabat bogomtaler; de skulle dels reklamere og inspirere læsere, og dels især være til hjælp og vejledning for samlingsbestyrerne. Tidligt i 1900-tallet etablerede de i realiteten en lille ny særoffentlighed parallelt med den klassiske reception i dagblades og litterære tidskrifters anmeldelser; i princippet tilgængelige for alle, men som jo mest til intern brug blev omtalerne en ekstra aktør eller institution inden i det litterære cirkulationssystem. De blev også meget omdiskuterede, både indefra og udefra; og det var netop især i forhold til den nye skønlitteratur de fremstod diskutable, med usikre faglige og 
æstetisk-kritiske holdepunkter og med ofte moralske og forenklede forståelser stammende fra de medvirkende læreres erfaringer med litteratur, børnelitteratur inklusive, i landbomiljøernes børneskole. Når en akademisk bibliotekar fra Statsbiblioteket (der var overcentral for folkebogsamlingerne) i 1914 sammenfattende misforholdet i denne nye litteraturreception: “Det er Akademikernes Skam, at de ikke i større Omfang, end sket er, har taget Del i Arbejdet.", ramte det præcist og understregede samtidig behovet for uddannede bibliotekarer (Hvenegaard Lassen, 1962, s. 182ff; Fog, 2014, s. 526ff).

Fra omkring 1918 fortsatte omtalepraksissen i tidsskriftet Bogens Verden (og Den nye Litteratur) - i en lang årrække i 1930erne blev al skønlitteratur varetaget af kun én person, bibliotekar Carl Jacobi fra Holbæk - men diskussioner af deres bonitet og funktion stoppede aldrig helt, bl.a. også fokuseret af oprøret i Biblioteks-debat i 1960erne. Det blev allerede tidligt anbefalet bibliotekarer/bogsamlingsledere at følge med i den traditionelle litteraturkritiks vurderinger og smagsdannelse - som en del af almen kulturel orientering, og anmeldelsesanalyse har også haft plads som en disciplin i uddannelsen. Pointen har oplagt været at den bibliotekariske stillingstagen til bøger er anderledes, har et andet blik, så bibliotekaren også bliver "kritikerens kritiker" (Lærebog, 1953: Bogvalg, s. 33). Det fik oplagt en socialiseringseffekt for professionen, men hvis det blik - hvad enten det gælder accession eller formidling - bliver til en mest system-intern kommunikation, tabes en del af forbindelsen til resten af det litterære liv; på børnelitteraturens område var det biblioteks- og skolesystemet der overhovedet etablerede en vurderingskritik. Da bogomtalerne blev skilt ud af Bogens verden i 1974 og overladt til fællesinstitutionen Indbindingscentralens som lektørudtalelser, fulgte det primært en systemintern effektivitet der trak væk fra en litterær offentlighed (- og ikke just med armslængde til den central der også skulle tjene på at levere bøgerne!). Hvad enten det hed omtale eller anmeldelse, karakteristik, anbefaling, eller evt. analyse mange betegnelser skiftende anvendt - fik den bibliotekariske kritik og vurdering efterhånden en lang selvstændig tradition; den er blevet trukket over i bibliotekspjecer og boglister, måske også i lokalaviser, og de seneste år på sites og hjemmesider, eller i den kortere form som note eller annotation der vandrede over i katalogiseringens kontrollerede kodesprog; eller den fik en mundtlig form som book talk eller i lånerdialog. Således blev den en effektiv systemkommunikation, men også den lille særoffentlighed der kan true med at lukke biblioteket af i forhold til en bredere litterær diskussion og kontekst.

Sammenhængende hermed kan man for det andet se på grundlaget for bibliotekarernes litteratur-faglighed der skulle sikre kvalitet og bredde midt i markedets løbende uoverskuelighed. Det kan følges hvordan man i opbygnings-årtierne fandt et undervisningsgrundlag på litteraturhistorieområdet, som var sigende for folkebibliotekernes/bibliotekarernes uddannelse og placering i litteraturoffentligheden. Da blikket i bogvalget $\mathrm{i}$ høj grad skulle rettes mod nyere tid og samtid, var universitetets akademiske overvejende bagudrettede forskningslitteratur ikke den mest oplagte, hvorimod de litteraturhistorier tidens frodige folkeoplysning havde tilvejebragt både var lettere tilgængeligt og langt mere ajourførte: således højskolemiljøet med et ajourført og fornyende oversigtsværk (den grundtvigske højskolemand Ejnar Skovrup: Hovedtræk af Nordisk Digtning $i$ Nytiden, I Danmark, II Island, Norge, Sverige, Finland, 1920-21), den nye type grundbog til studekredsmiljøet (forskningsbibliotekaren Helge Topsøe-Jensen: Den skandinaviske Litteratur, 1928, opr. skrevet til en hollandsk populærvidenskabelig serie, og udkommet i en tidstypisk dansk håndbogsserie), arbejderoplysningens marxistisk orienterede litteraturtilgang (arbejderhøjskolemanden og socialdemokraten Julius Bomholt: Moderne Skribenter, 1933) og i 1947 en dansk oversættelse af den succesfulde norske bog fra en folkeoplysningsserie (De tusen hjems bibliotek, Oslo-professor Francis Bulls Verdenslitteraturens historie, 1941) samt flere tilsvarende lettilgængelige oversigter, hertil dels nogle solide standardbøger til gymnasie- og seminariebrug, (lærerhøjskoleog folkeuniversitetsmanden Georg Christensen: Dansk litteratur, 1916-40 og senere gymnasielektoren Svend Norrild: Dansk litteratur, 1939-60, begge i mange udgaver). Arbejdet i biblioteket syntes tydeligt at lægge sig på linje - ligefrem i alliance - med en bred folkelig konjunktur, der var med til at placere litteraturforståelsen et andet sted end i det akademiske studie. Proto-eksemplet på tidens forening af faglighed og folkelighed, det brede galleriværk Danske Digtere i det 20. Aarhundrede fra 1951, tog folkebiblioteksmiljøet helt præcist til sig med den begejstring som dets mange senere udgaver bekræftede for det danske litterære liv. 
Vægten på læsning af og orientering i skønlitteratur fortsatte i den udbyggede uddannelse efter 1956, og i 197080ernes ekspanderende uddannelse og efteruddannelse ligeledes, især med en genreorientering, indføring i litteraturkritikteori og litteratursociologi samt andre dele af akademisk litteraturvidenskab, der også var blevet historisk bedre ajourført; hertil kom den forskning Biblioteksskolens egne litteraturundervisere efterhånden producerede. Da uddannelsen fik universitetsstatus og kandidatuddannelse, svandt undervisningen i de litterære områder gradvist ind og forsvandt som obligatorisk omkring 2010-12 og siden næste helt (Lærebog, 1945; 1953; 1959; Iversen, 1981; Anmeldelse af Danske Digtere i det 20. Århundrede, 1952, s. 42f; Winge, 1976, s. 171-191).

\section{Fluktuerende brug af tidsskrifter}

Som en del af diskussionen af en særoffentlighed kan som nævnt ses bibliotekets forhold til på litteraturområdet. Folkebibliotekerne tog også plads i særlige kredsløb og deloffentligheder via tidsskrifter. Foreningen Danmarks Folkebogsamlingers Bogsamlingsbladet (1906-20) kan ses som det første der skrev om litteratur i en ny kontekst, herunder med de anmeldende omtaler. Tidens altdominerende forlag var imidlertid også i gang, Gyldendal havde påbegyndt en strategisk satsning helt samtidig med en ny type orienteringsblad for publikum Læsning for Folket (1906-11); det blev videreført fra 1911 som Bogvennen. Gyldendals Litteraturtidende der skulle "... bringe Publikum og Forfattere i Kontakt med hinanden" (jan. 1912), og et femcifret oplagstal og en stor dynamik med moderne art litteraturjournalistik gjorde det hurtigt til et 14-dagsblad. Men det fluktuerede også med skiftende undertitler og redaktioner, indtil det i 1916 udvidedes med dels en kendt litteraturkritiker fra Social-Demokraten, dels bibliotekar Thomas Døssing fra Statens Bogsamlingskomite, der netop tog sig af en speciel sektion: Bibliotekstidende - med $\emptyset$ get vægt på autoritativ bogkritik, biblioteksstof og et tidsskriftindeks. Med en forlagskrise stoppede Gyldendal Bogvennen, og et ny tidskrift Bogens Verden. Tidsskrift for dansk Oplysningsarbejde opstod udgivet af den nystartede Danmarks Biblioteksforening i samarbejde med den ligeledes nystartede Studiekredsforening, og som ikke mindst også indeholdt anmeldende omtaler. Det holdt i fire år indtil sidstnævnte hoppede fra og påbegyndte eget tidskrift Læsning, medens førstnævnte fra 1923-31 supplerede med Den nye Litteratur. Dansk Litteraturtidende under redaktion af Svend Dahl, en af tidens indflydelsesrige i biblioteksvæsenet. "Der er ingen Mangel på litterær Interesse i Danmark" Iød startskuddet i lanceringen i første nummer, og da en af begrundelserne heri var de offentlige bibliotekers hastigt voksende udlånstal, var udgiverens formål at lave et litterært fagtidsskrift der kunne få oplysning og vejledning vidt ud. Den nyudgivne skønlitteratur og faglitteratur af almen interesse fik samlet årligt 150-200 omtaler, skønlitteratur forstået bredt inklusive kriminallitteratur. Det var karakteriserende omtale snarere end æstetisk kritik - en sondring der også fandtes i Bogsamlingsbladets og Bogens Verdens bogstof - og som skulle blive en langvarig udfordring. Den nye Litteratur forbandt sig med flere af tidens yngre toneangivende og flittige litterater og momentvis universitetsfolk, men fluktuerede meget i søgen efter sin plads og allierede, og det kunne næppe kaldes stærkt fornyende endsige layoutmæssigt inspireret af Bauhaus! Det holdt i otte år og udvidede fra 1928 udgiversiden med Københavns Boghandlerforening og Den danske Boghandlerforening, hvorefter bibliotekssektoren i 1931 trak sig ud, og bladet fortsatte fra bogbranchen alene. Samme år meldte Gyldendal sig igen med bladet Meddelelser fra Gyldendal. Det væsentlige er at folkebibliotekets folk navigerede, associerede sig og invaderede rundt, som de nye aktører de var i det litterære liv, samtidig med at alle i branchen havde set den nye biblioteksinstitutionalisering komme.

Bogens Verden kunne som foreningsorgan i stedet samle sig om biblioteksstof, og blev ikke specielt litterært orienteret. Fra 1931 måtte det dog genoptage væsenets egne bog- og litteraturomtaler. Under 1940ernes store litteraturkonjunktur opstod det uafhængige tidsskrift Boganmelderen hvis bogomtaler blev oplagt brugbare for både læsere og bibliotekarer igennem tre årtier; bogbranchen etablerede fra 1948 Det danske Bogmarked med en $\mid \varnothing$ bende uundværlig bogudgivelsesregistrering, medens Biblioteksnyt. Folkebibliotekernes Publikumsblad 1945-71 som et lille uprætentiøst publikumsblad med småartikler og anbefalinger varetog en lånerkontakt, medens Biblioteksdebat var en kritisk generationsplatform 1965-71 (se ovenfor).

Bogens verden med biblioteksforeningen som udgiver var fremdeles væsenets store stabile organ, og de løbende boganmeldelser holdt til 1974 hvor de blev skilt ud og lagt i alene Indbindingscentralens regi som lektørudtalelser ('de grønne sedler'). Fra 1983 fik tidsskriftet et skærpet fokus på litteratur (med en af Danmarks markante 
kritikere Erik Skyum-Nielsen i redaktionen de næste 14 år), en linje der fortsatte fra 1997, hvor det dog ophørte med at være egentlig medlemsblad for Biblioteksforeningens medlemmer (der i stedet fik Danmarks Biblioteker - uden noget litteraturstof). Det tog nu status som et alment kulturelt/litterært tidsskrift, hvor det bl.a. via årsrapporter om markedets nye bøger og via netværket Den litterære institution uss (1983 -) forbandt biblioteket med andre aktører i det litterære liv. Men dets skæbne blev herefter også blandinger af skiftende udgivere, foruden den oprindelige forening således Biblioteksstyrelsen, Danmarks Biblioteksskole, Det Kongelige Bibliotek, Det Danske Forfatter- og Oversættercenter Hald med samt redaktører fra disse institutioner - foruden et litteraturinstitut under Aarhus Universitet. Biblioteksskolen trak sig efter at skønlitteraturen synligt var svundet ind $\mathrm{i}$ både uddannelsen og efteruddannelsen, og Bogens verden stoppede med udgangen af 2011, som mange andre fysiske abonnement-tidsskrifter ramt af dels kampen mod de digitale og dels indskrænkninger på kulturområdet efter finanskrise og kommunalreform. Et af Danmarks længstlevende kulturtidsskrifter fremviste med skiftende medspillere således næsten samme fluktureren i sine sidste år som i sine første: strategisk famlende indgang i det litterære liv og adstadigt klamrende afgang. Bibliotekets plads i det litterære liv svandt her - som en del af de sidste 10-20 års voldsomme forandring af det litterære tidskriftlandskab.

\section{Folkebiblioteket som producerende og formidlende i litteraturlivet midt i århundredet}

Besættelsestiden i Danmark var en stor læsetid, og 1940-50erne igennem var konjunkturen for litterær interesse høj: i forlagsudgivelser, oplysningsbøger og håndbøger for både læg og lærd, i studiekredse, i radioen, i søgningen til universitetsstudier etc. Da Politikens forlag som noget helt nyt udsendte håndbogen Hvem skrev hvad? i 194546 i to oplag, viste de i alt 30.000 eksemplarer en markant grobund, og den var i opbygning og funktion som skræddersyet til folkebibliotekerne - der også tog dem til sig på en måde som gjorde det næsten selvfølgeligt at ajourføringen og udbygningen af dette håndbogssystem blev varetaget af Biblioteksskolemiljøet. Og da et nyt nationalbibliografisk flagskibs-projekt Dansk Skønlitterært Forfatterleksikon 1900-1950 (I-III, 1959-64) nogenlunde samtidig blev sat i søen, var det fremdeles med folkebiblioteksledere i styregruppen. Biblioteksårbogen - siden 1940 udgivet af folkebiblioteksforeningen - viste i sine statistikker voldsom fremgang $\mathrm{i}$ udlån, og især af skønlitteraturen. Fra 1940erne var folkebiblioteket så etableret og anerkendt at den kunne

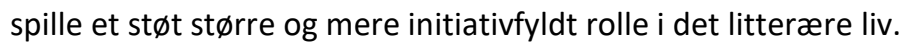

Et af initiativerne var etableringen af Studiekreds-Centralen i 1938-41 som en fællesinstitution mellem en række folkebiblioteker og Arbejdernes Oplysnings Forbund, på grundlag af en statslig startbevilling og siden finansieret af folkebibliotekerne selv. Formålet var at sikre en låneforsyning af supplerende faglig litteratur (ikke de egentlige grundbøger, som deltagerne normalt købte) til studiekredsene, som de enkelte biblioteker ikke kunne klare efterspørgslen på, og i øvrigt at yde service og information til st $\varnothing$ tte for studiekredsarbejdet. Tanken og $\emptyset$ nsket havde været formuleret allerede omkring Studiekredsforeningen i 1920erne og således været længe undervejs. Finanslovsbevillingen i 1938 blev den første direkte officielle statslige anerkendelse af det frie oplysningsarbejdes studiekredsvirksomhed, der dog undervejs havde fået en del støtte fra bibliotekerne.

Med en placering på Statsbiblioteket i Aarhus og en styregruppe opbyggedes på få år en bogbestand i et stort eksemplartal til et st $\varnothing t$ stigende udlån til folkebibliotekerne eller direkte til studiekredsene. Med beskedne midler fungerede systemet efter formålet og i kontakt med fx Statsradiofonien og Dansk Ungdoms Samvirke. For biblioteksfolk var det en klar markering af formidling af bred faglig oplysningslitteratur som noget primært; bestanden viste præcist tidens anerkendte standard, som også fandtes i folkebibliotekernes mønsterliste, ligesom det understregede den gamle praksis at Statsbiblioteket ikke udlånte skønlitteratur.

Succesen trak imidlertid en uforudset udvikling med sig. Studiekredsarbejdet med litteratur ekspanderede i 1940erne så kraftigt, at efterspørgslen på lån af skønlitterære værker steg, og i 1949 begyndte centralen derfor at opbygge en samling af skønlitteratur til udlån i sæt. Tanken havde været der fra begyndelsen, men pga. både $\emptyset$ konomi og den klassiske forestilling om faglitteraturens primat havde man holdt sig tilbage. Da der blev 'givet efter' for efterspørgslen, gik udviklingen på få år så stærkt at stigningen i centralens bogbestand og udlån næsten alene skyldtes skønlitteratur. Fra midten af 1950erne lå hovedvægten af al anskaffelse og genanskaffelse og næsten hele udlånet i mange eksemplarer her, medens faglitteraturen svandt ind - en næsten selvforstærkende 
mekanisme. I tal drejede det sig eksempelvis i 1955-56 om udlån af 6000 eksemplarer af skønlitterære værker, svarende til en forsyning med sæt til omkring 5-600 studiekredse landet over, medens udlånet af faglitteratur kun udgjorde godt 700 eksemplarer i alt. Efterspørgslen gik yderligere i stigende grad gik uden om den anerkendte nyere (sociale og nationale) kanon som bibliotekarerne ellers prioriterede, idet den nye læsekonjunktur i takt med opmærksomhedskoncentrationen i den litterære offentlighed søgte det helt aktuelle ( $\mathrm{fx}$ Martin A Hansen, Branner og Lagerkvist). "Det ser ud, som om folk i stigende grad benytter sig af studiekredsformen for i fællesskab at diskutere og bedre at søge at forstå de mere vanskeligt tilgængelige skønlitterære bøger." hed det i Slagelse Centralbiblioteks beretning for 1954-55, (Omtale af litterære studiekredse, 1955, s. 313), og det var vurderingen i centralen at efterspørgslen på skønlitteraturen især skyldtes kvindernes stigende deltagelse i studiekredse.

Tanken bag centralen var service indrettet efter brugernes $\emptyset$ nsker og behov. Men man havde ikke forudset den vending der på ganske få år gik fra en oplysningstankegang funderet på udbredelse af god faglig litteratur, selektivt og under knappe ressourcer, til en halvautomatisk og efterspørgselsstyret skønlitterær forsyningsvirksomhed, bekvemt funderet på stigende ressourcer. Først i slutningen af 1960erne, da højskoler og andre skoler var begyndt at rekvirere bogsæt ('klassesæt') fra centralen, omlagdes funktionen i forbindelse med oprettelse af Amtscentraler og Folkebibliotekernes Depotbibliotek (Biblioteksårbogen 1940-1960; Sejr, 1940; Thomsen, 1945; Thomsen, 1942, s. 274; jfr. Holt Kjær, 1987).

Studiekredscentralen var 'forsinket' ca. 15 år fordi folkebibliotekerne i 1920erne ikke var (politisk) stærke nok til at støtte denne del af voksenoplysningen. Den ikke-tilsigtede udvikling centralen dernæst tog i 1940erne bar endog en art paradoks med sig - at biblioteksidealer kan punktere i takt med fremdrift og indfrielse. Hverken et fænomen som efterspørgselspres, der blev voldsomt diagnosticeret i 1980erne (jfr. ovenfor), eller en praksis som nutidens populære bogkasser til skønlitterære læsekredse savner således heller ikke historie bagud.

Selv om der tidligt var samarbejde med Studiekredsforeningen (om bl.a. tidsskriftet Bogens Verden), havde folkebibliotekerne distanceret sig fra studiekredsbevægelsen, der især efter AOFs start i 1924 blev opfattet som mere politisk end bibliotekets neutralitetsideal. Men med den store konjunktur i 1940erne (og efter Socialdemokratiet var blevet et folkeparti), spillede biblioteksinstitutionen mere med, bl.a. med udarbejdelse af studievejledninger. Det helt fremragende eksempel fandtes netop også i et af flagskibene, Statsradiofoniens grundbog Danske Samfundsromaner - med radioudsendelser - fra 1946, som (den helt nyuddannede) bibliotekar Ole Hovman med udførlighed og sammenhæng efter tidens ideale principper stod for. Der var orden og ajourført bibliografi, klart sigte og niveaudifferentiering i opgaver/spørgsmål til kredsmedlemmernes diskussioner af de i alt otte romaner: til forfatterskab, virkelighedsbaggrund, andre beslægtede forfattere, vurderinger og læsetilskyndelser. Vejledningen rummede den klare pointe, at litteraturen om den nyere skønlitteratur og dens forfattere var skrevet bredt tilgængelig - det var folkeoplysningens og ikke forskningens område, dansksproget og af dansk oprindelse til den interesserede danske læser. Det var folkebibliotekslitteratur, ikke universitetsbibliotekslitteratur - og det var rettidig omhu med at forene skønlitteratur med faglig oplysning og forene radio og bibliotek.

Et andet eksempel udgør en lille litteraturhistorisk grundbog Dansk Litteratur efter 1920. Oversigt til Brug for Studiekredse fra 1943 (i serien Studenterforeningens danske Bibliotek, der også omfattede andre litteraturhistoriske bøger). Den viste interesse for den nærmeste samtidslitteratur med dels nogle tematiske snit, dels mange små forfatterskabsomtaler/biobibliografier der gav den præg af håndbog med en referencedel ajourført og afvejet efter tilgængelighed. Den forenede en sociologisk orientering fra AOFs oplysningslinje, stærk inspiration fra akademiske afhandlinger og aktuelle forfattergalleribøger. Med netop den udformning og pædagogiske præcision var bogen interessant ved at være skrevet af en bibliotekar, Anna Elise Møldrup der som også cand.mag. i dansk selv havde ledet og berettet om litterære studiekredse, medens hun umiddelbart forinden var på Statens Biblioteksskole (Socialisten, 1942 s. 242-45); folkebibliotekarer var ikke ellers et meget skrivende folk, og en kvinde der publicerede litteraturhistorie var fremdeles dengang en sjældenhed - skønt hun i bibliotekarstanden tilhørte et flertal. 
Et tredje initiativ med langtrækkende effekt var Læs med Plan. Litteraturvejledninger udgivet af danske Folkebiblioteker der i 1942 iværksattes som noget nyt i det udadvendte arbejde, ikke mindst for skønlitteraturen. Carl Thomsen fra Aarhus Folkebiblioteker gav udspillet, og kollegaen Preben Kirkegaard skildrede i en principiel artikel i Bogens Verden hvorledes katalogapparatet, især emnekatalogen, kunne forbedres og lånernes vej ind $\mathrm{i}$ bogbestanden kunne stimuleres og tilrettelægges efter "laaner-psykologiske" principper - frem for læsning i flæng eller tilfældigheder i valg af bøger: som et lille sagligt hæfte, i hånden og gratis med hjem til ejendom, og samtidig en centralt styret udbygning af emneorienterede mønsterlister til lokal bibliotekarbrug. "Det skal ikke være kritisk videnskabelig litteraturgennemgang, men biblioteksservice i top form." Efter kort tid slog forsøget og begrundelserne an, og de små vejledninger på seks sider i vekslende farver blev overtaget som fællesforetagende af Folkebibliotekernes bibliografiske Kontor: ca. seks vejledninger om året, et oplag på 6000 der efter få år steg til 10.000, og de mest efterspurgte med ofte et langt liv i reviderede udgaver. Det var en centralt styret folkebiblioteksoffensiv der udnyttede tidens voksenoplysningskonjunktur, men anderledes end studiekredstraditionens studievejledninger skulle det være individuelt rettede læsevejledninger; en studiestruktur måtte ikke overskygge det fleksibelt og overskueligt indbydende hjælpemiddel for den enkelte låner (Bibliotekstjänst påbegyndte en pendant i 1951 i Sverige).

I forhold til den klassiske bibliotekstanke rettet mod faglitteraturen pegede to tredjedel af biblioteksudlånet på at de skønlitterære forfattere og litteraturhistorien fik stor plads i Læs med Plan; de udgjorde ca. halvdelen af vejledningerne de første årtier, i nogle år dominerede de ligefrem. Der var to hovedtyper: den ene - og prioriterede - type orienteredes mod emne - Det moderne Amerikas Litteratur, Børnepsykologiske Romaner, Antifascistiske romaner - der rummede både kvalitet, aktualitet og holdning, og som lignede avancerede udgaver af de genrelister, bibliotekerne også havde påbegyndt (delvis som en slags anbefalende bibliografi i et spor især AOF havde lagt ud), ligesom skønlitteratur integreredes i egentlige faglitterære emnevejledninger.

Den anden hovedtype gjaldt enkelt-forfatterskabet. De første 15 år blev der udarbejdet i alt 40 forfattervejledninger; det var således en lille begivenhed da den første kom i 1943 om Henrik Pontoppidan, ved bibliotekar - og cand.mag. i dansk - Oluf Abitz fra Vejle, for især disse skulle i legio antal blive et af biblioteksinstitutionens sikre kort i årtier frem - fra 1970erne med betegnelsen en bogliste og årtiet efter - mere retmæssigt - et forfatterportræt fra biblioteket. Reelt genoptog biblioteket et fokus som studiekredsforeningen havde slået an i 1920erne, og overhovedet var den lette biobibliografiske forfatterpræsentation i forskelige galleribøger etc. meget udbredt og populær her midt i århundredet som formidlingsgenre. Pjecerne udviklede sig hurtigt fra den lidt respektfulde litteraturhistorie-holdning til det mere dynamisk portrætterende $i$ en personlig udformning, tidstypisk også med både eksistentielle træk og nykritisk værkfokus, især da samtidsforfatterne kom mere med, og man efter 1960 åbnede for de udenlandske.

Man holdt sig typisk på sikker grund inden for litteraturlivets accept, pjecerne var nyskrevne små koncentrater, og de havde et engagement, der st $\varnothing t$ blev tydeligere; skribenterne var en blanding af bibliotekarer og folk udefra: kritikere, forskere, oversættere, højskolefolk etc. De blev dels en lille platform for de ellers ikke meget skrivende bibliotekarer, og dels en forbindelseslinje til litteraturlivets $\varnothing$ vrige (interesserede) folk - som efterhånden mest tog over.

Levedygtigheden holdt årtier frem og findes fortsat både omkring emner og enkeltforfattere i såvel trykt som online format; de vigtige og st $\varnothing t$ voksende centrale litteratur-baser som forfatter-/litteraturleksikonet Forfatterweb.dk (1996-) og servicesitet Litteratursiden.dk (2001-) har bygget videre på den formidlingsmodel der havde faglighed, enhedspræg, regelmæssighed, kontinuitet og effektiv udbredelse - en institution inden i biblioteksinstitutionen. "Hvornår får vi det rigtige Litteraturleksikon" spurgte biblioteksdirektør og magister Robert L. Hansens anmeldelse i 1945 da Politikens berømte Hvem skrev hvad? udkom. Det fik man da bibliotekerne 50-60 år efter byggede Læs med Plan-traditionen sammen med digitale tjenester og fastholdt bibliotekerne nytte for litteraturlivet (Kirkegaard, 1942, s. 365-68; Allerslev Jensen, 1979, s. 78ff; Hansen, 1945, s. 303). 


\section{Påviselig, mangfoldig og uvurderlig betydning - en kort status i dag}

Folkebibliotekerne er stadig en kulturpolitisk prioriteret aktør med betydning for det litterære liv, men en del er ændret gennem de ca. 100 år. De aftager stadig af forlagsproduktionen, men i andre former end den trykte bog og med nye aftaler og er ikke i samme grad sikkerhedsnet under udgivelser. Indkøbet er stadig efterspørgselsorienteret, markedets radier har erstattet litteraturautoriteter, der kasseres st $\varnothing t$ mere og folkebiblioteket bliver i mindre grad bogsamling/-lagre, hukommelsen forkortes. Udlånet af skønlitteratur har været faldende - og dermed er dele af cirkulationen og læsemønstre under ændring. Traditionen for litteraturfokus i bibliotekaruddannelsen er gledet ud det seneste årti, den sektorrettede bibliotekaruddannelse er væk, og kompetencerne på litteraturområdet må bibliotekerne hente via andre universitetsuddannelser. Forpligtelsen på litteraturhistorien og inspiration fra litteraturforskningen er løsnet, ligesom forbindelsen til det ellers stigende antal litterære selskaber kun synes sporadisk - som det ses $i$ en behersket opslutning om den årlige Klassikerdagen (klassikerdagen.dk). Identifikationen med litteraturkritikkens tænkning og værdi er også svækket, tidligere relevante litterære tidsskrifter er skiftet ud med forskellige anbefalingssitesites og blogs, medens lektørudtalelserne forvaltes i eget lukket system, ligesom eksempelvis Danmarks Biblioteksforenings Læsernes bogpris i samarbejde med Berlingske Tidende (2004 -) snarere er offentlig virak end litteraturvurdering. De forbindelseslinjer der tidligere var til dansk folkeoplysnings andre organiseringer eksisterer næppe mere, med et samarbejde med Danmarks Radios romanlæseklub og romanpris (1999 -) som en velanbragt undtagelse, ligesom samarbejde/partnerskab med andre aktører i det litterære liv synes mere ad hoc end strukturelt. Kulturpolitisk er der kun en tynd lovgivning og få ressourcer rettet direkte mod det skønlitterære område - hvor dansk i stigende grad er truet som sprog. Biblioteksafgiften er livsvigtig som kunststøtte til forfatterne, men samtidig en kolos med flere iboende paradokser.

Midt i disse ændringer og fortrædeligheder er der dog også fremvokset nye typer litterært liv; det der er blevet kaldt den performative fase og oplevelsesparadigmet i litteraturformidlingen (Grøn, 2010) med god grøde i folkebibliotekernes litteraturformidling gennem de sidste 10-15 år, fokuseret bredt og initiativrigt nedefra og st $\varnothing$ ttet strategisk oppefra, prioriteret i fx betænkningen Folkebibliotekerne i vidensamfundet (2010) og fulgt op af statsstøtte til mange projekter. Midt gennem på den ene side brugerstyring, selvbetjening og digital kommunikation som praktisk profil, og på den anden side $\emptyset g$ get vægt på læseren - frem for på litteraturen, på oplevelse og det personlige, på mundtlighed og lyd samt på iscenesættelse, performance og samvær har netop skønlitteraturen været den ytringsform der mest og lettest forenedes med klassisk læsning og fysisk bogmedie. Folkebiblioteket fik i digitaliserings-alderen et menneskeligt ansigt ved at holde fast i skønlitteraturen på en ny måde, strategisk med en kreativ udvikling, dedikerede initiativer og nye kompetencer. Bidraget til det litterære liv var bl.a. mere dialog og interaktive sites - frem for trykte foldere, det var læsekredse, shared reading og vækst i forfatterarrangementer (støttet af Kunstfondens Forfattercentrum), det var nye typer samarbejder med skoler og børneinstitutioner, medens den obligate partnerskabstænkning især fandt vej omkring det litterære livs nye events, festivaler som Verdenslitteratur på Møn (2000 -), Krimiessen i Horsens (2001 -), København læser (2008 -), nORD i Helsing ør (2016 -) og LiteratureXchange i Aarhus (2018 -). Biblioteket holder sig stadig vitalt afsøgende, og til det positive hører at meget af dette, både det hensygnede og de nye livliner, diskuteres med betydelig offentlig bevågenhed.

Ejnar Thomsens fornemmelse havde en del for sig: folkebibliotekerne fik en betydning for det litterære liv der har været klart påviselig, mangfoldig - og vist uvurderlig nok. 


\section{Referencer}

Allerslev Jensen, E. (1979). Bibliotekscentralens forhistorie og første år. Ballerup: Bibliotekscentralen.

Andersen, V. (1970). Dansk litteratur. Forskning og undervisning (1912). København: Gyldendal.

Andreasen, T. (2006). Bok-Norge. En litteratursociologisk oversikt [2. udg.]. Oslo: Universitetsforlaget.

Anmeldelse af Danske Digtere i det 20 Aarhundrede. (1952). Bogens Verden, $42 f$.

Bay, C. E. \& Jørgensen, J. C. (Red.) (1979). Litteratur og samfund i mellemkrigstiden. Litteratursociologiske studier. København: Gyldendal.

Biblioteksaarbog (1940 -). København: Danmarks Biblioteksforening/Biblioteksstyrelsen.

Bogfortegnelse for mindre Biblioteker (1923) udgivet af Centralbibliotekarernes Sammenslutning, København.

Bøger i Danmark. Bogudvalgets betænkning (1981). København: Kulturministeriet.

Elberling, B. V. \& Bruhns I. (1967). Læste bøger. Voksnes læsning og biblioteksbenyttelse. 2.udg. (1. udg. 1965) Skrifter fra Danmarks Biblioteksskoles sociologisk laboratorium /1. København: Danmarks Biblioteksskole.

En politik for litteraturen (1994). Købehavn: Kulturministeriet.

Escarpit, R. (1972). Bogen og læseren. Litteratursociologi. Tillæg af Hans Hertel: Det litterære Danmark. København: Hans Reitzel.

Fog, E. (1913-14). Publikum og Biblioteker. Gad Danske Magasin, 526-28.

Folkebibliotekerne i vidensamfundet (2010). København: Styrelsen for bibliotek og medier.

Fortegnelse over Bøger passende for Sogne- og Landbrugsbiblioteker. Tillæg 1902, udg. af Landhusholdningsselskabet (opr. udg. 1889).

Frøland, A. (1974). Dansk boghandels historie 1482-1945. København: Gyldendal.

Furuland, L., (1989). Litteratur och samhälle. Om litteartursociologin och dess forskningsuppgifter. I E. MunchPetersen (Red.). Litteratursociologi. En antologi (s. 14-48). København: Bibliotekscentralen.

Grøn, R. (2010). Oplevelsens rammer. Former og rationaler i den aktuelle formidling af skønlitteratur for voksne på danske folkebiblioteker. Aalborg: Danmarks Biblioteksskole.

Grøn, R. \& Balling, G. (2012). Litteraturformidling og bibliotekaren som faglig - personlig formidlingsautoritet. Nordisk Tidsskrift for Informationsvidenskab og Kulturformidling, 1(3), 51-61.

Handesten, L (2018). Litteraturen rundt. Aktører i det litterære felt. København: Samfundslitteratur.

Hansen R. L. (1937). Om Uddannelse af Bibliotekarer ved Folkebibliotekerne. I: Danske Folkebiblioteker. København: Bibliotekarsammenslutningen for Folkebibliotekerne.

Hansen R. L. (1945). [anmeldelse af Hvem skrev hvad]. Bogens Verden, 303.

Hertel, H. (1999). Litteraturens vaneforbrydere. Kritikere, forlæggere og lystlæsere - det litterære liv i Danmark gennem 200 år. København: Forening for Boghåndværk. 
Hjermind, E. W. \& Ørom, A. (1981). Bibliotekarisk selvforståelse: En analyse af perioden 1930-64.

Biblioteksarbejde 4, 7-55.

Holt Kjær, B. (1987). Viden er vækst. Studiekredsene og bibliotekerne 1910-1950. København: Danmarks Biblioteksskole.

Houmøller, S. (red.) (1963). Den danske Bibliotekarstand (1963). 2. udg., København: Bibliotekscentralen. Hvem læser hvad i Silkeborg? (1944). Bogens verden, 152-154

Hvenegaard Lassen, H. (1962). De danske folkebibliotekers historie 1876-1940. København: Dansk Bibliografisk Kontor.

Iversen, M. (1944). Ungdommens Bogudstilling. Bogens Verden, 260.

Iversen, M. (1981). Bibliotekaruddannelserne i Danmark 1918-1978. København: Gad.

Japsen, A. (1992). Biblioteket og den gode bog. København: Gyldendal.

Johansen, A. \& Søholm, E. (Red.) (1996). Femøren der voksede Biblioteksafgiften 1946-1996. København:

Statens Bibliotekstjeneste.

Karner Smidt J. et al. (Red.) (2013). Litteratursociologiske perspektiv. Oslo: Universitetsforlaget.

Kirkegaard, P. (1942). Katalog og Publikum. Bogens Verden, 365-68.

Lange, H. O. (1916-17). Bibliotekernes Betydning for Valget af Læsning. Bogvennen I, 23-26.

Lund, N. D. (2000). Mellem folk og fagfolk. Den litteraturfaglige litteratur og folkeoplysningen i Danmarks ca. 1895-1960 (ph.d.-afhandling). København: Københavns Universitet.

Lund, N. D. (2001). Litteraturformidlingens betingelser. Biblioteksarbejde nr. 61, 7-23.

Lærebog i Biblioteksteknik (1922, 1945, 1953, 1959). 1-4.udg. København: Statens

Bogsamlingskomite/Folkebibliotekernes Bibliografiske Kontor/Dansk bibliografisk kontor.

Munch-Petersen, E. (Red.) (1995). Litteratursociologi. En antologi. 2. udg. København: Bibliotekscentralen. (1. udg. 1989).

Møldrup, A. E. (1942). En Vinter med Bøger. Socialisten, 242-45.

Omtale af litterære studiekredse. (1955). Bogens Verden, 313.

Omtaler af skønlitteratur. (1911-12) Bogsamlingsbladet 20-23.

Rabatspørgsmålet. (1906). Bogsamlingsbladet 7-9.

Secher, C. (1995). Folkebibliotekerne og den litterære kvalitetsdebat i Danmark. I E. Munch-Petersen (Red.). Litteratursociologi. En antologi. 2. udg. (s. 150-172). København: Bibliotekscentralen.

Secher, C. (2000). Bibliotekernes og lånernes skønlitterære bogvalg. København: Biblioteksstyrelsen.

Sejr, E. (1940). Overcentralen og Studiekredsbiblioteket. Bibliotekaren nr. 5, 74-82.

Skouvig, L. (2004). De danske folkebiblioteker ca. 1880-1920 (ph.d.-afhandling). København: Danmarks Biblioteksskole 
Skovgaard-Petersen, V. (1976). Dannelse og demokrati. Fra latin- til almenskole. Lov om højere almenskoler 24. april 1903. København: Gyldendal.

Steiner, A. (2009). Litteraturen i mediesamhället. Lund: Studentlitteratur.

Svedjedal, J. (1993). Bokens samhälle. Svenska Bokförläggareföreningen och svensk bokmarknad 1887-1943 III. Stockholm: Svenska Bokförläggareföreningen.

Svedjedal, J. (2012). Det litteratursociologiske perspektivet. I J. Svedjedal (Red.) Litteratursociologi. Texter om litteratur och samhälle (1. udg. 1997), Lund: Studentlitteratur, 73-100

Thomsen, C. (1942). Studiekredscentralen i funktion. Bogens Verden, 16, 274.

Thomsen, C. (1945). Bibliotek og Publikum. I Lærebog i Biblioteksteknik. København: Folkebibliotekernes bibliografisk Kontor, 158-169.

Thomsen, E. (1935). Dansk Litteratur efter 1870. Med Sideblik til det øvrige Norden. En Hjælpe- og Arbejdsbog til højere Undervisning samt til Kreds- og Selvstudium. København: Hirschsprung.

Weinreich T. (1985). Børns bøger. Bogen, barnet og skolen. København: Høst \& Søn.

Winge, M. (1976). Dansk børnelitteratur 1900-1945 - med særligt henblik på børneromanen. København: Gyldendal.

Winge, M. (1979). Bøger og brugere - omkring det litterære system. København: Schultz.

Worsøe-Schmidt, L. (1994). Litteraturen situation og litteraturpolitikken 1961-93. Århus: Klim.

Worsøe-Schmidt, L. (1997). Sæt pris på bogen. En undersøgelse af danske bogpriser 1980-1994. København: Statens Bibliotekstjeneste.

Worsøe-Schmidt, L. (2017). The e-book war in Denmark. Jolis I-II, 1-11. 